\title{
В. М. Соколов,
}

член-кореспондент НАAН, директор

Селекційно-генетичний інститут -

Національний центр насіннєзнавства та сортовивчення

у 2012 р. Селекційногенетичний інститут, провідна установа української аграрної науки в галузі вивчення теоретичних основ продуційного процесу та виведення сортів і гібридів польових культур відзначає свій 100-річний ювілей. Створення і розвиток інституту тісно пов'язані зі становленням вітчизняної селекції рослин, 3 багатьма політичними і економічними подіями у житті країни. Так, намагання сприяти розвитку землеробства у південному регіоні, використовуючи для цього наукові розробки, мали місце ще наприкінці XIX сторіччя. Зокрема в 1895 р. на околиці Одеси було відкрите Дослідне поле із завданнями вивчення сівозмін, строків сівби, боротьби з бур'янами і т. ін. Але виведення місцевих, адаптованих до умов південного степу сортів польових культур залишалося поза увагою, поки у 1912 р. Комітетом 3 управління одеським Дослідним полем не було прийняте рішення щодо створення тут відділу селекції, який очолив доцент Новоросійського університету А. О. Сапєгін, у подальшому доктор наук, професор, академік та віце-президент АН УРСР.

На той час відсутність місцевих сортів вже почала істотно обмежувати розвиток товарного аграрного виробництва. Землеробство в Степу було ризикованим через літні посухи, напади шкідників, морозні зими. Іноземні сорти справу не вирішували, а навіть погіршували внаслідок повної невідповідності таким жорстким умовам вегетації.

\section{Селекційно-генетигному iнcmumymy - 100 poкib}

А. О. Сапєгін багато зробив для розвитку селекційної справи та установи, якою керував. Навесні 1918 р. на базі селекційного відділу Дослідного поля та розсадника кормових культур була створена Одеська селекційна станція. У січні 1923 р. вона увійшла до складу Крайової сільськогосподарської дослідної станції. Наукова програма включала селекційну роботу з пшеницею, ячменем, соняшником, картоплею, суданською травою, овочевими культурами. Як результат, у 20-ті роки в аграрне виробництво впроваджуються перші в історії степового землеробства вітчизняні сорти озимої пшениці- Кооператорка, Земка, Степнячка, створені А. О. Сапєгіним. Посівна площа Кооператорки швидко сягнула рекордних 5 млн га. Цьому сорту також належить рекорд 3 довголіття у виробництві.

На жаль, подальші події жорсткі зими 1927/28 і 1928/29 років призвели до майже повної загибелі посівів озимої пшениці на півдні країни, але, у той же час, переконливо засвідчили необхідність створення крупної аграрної науково-дослідної установи у цьому регіоні. Тому у жовтні 1928 р. на базі селекційної станції створюється Український генетико-селекційний інститут з відділами генетики, селекції, фізіології, захисту рослин, сортовивчення і техноаналітики. В 1934 г. його статус підвищується - він стає Всесоюзним селекційно-генетичним інституTOM (ВСГI).

Розглядаючи пройдений установою шлях можна стверджува- ти, що протягом усіх років, починаючи з фундатора установи А. О. Сапєгіна, основними напрямами робіт були розробка важливіших питань теорії селекції, насінництва, наукове забезпечення і удосконалення селекційного процесу та створення на цій основі адаптованих до умов вирощування у регіоні сортів, гібридів польових культур. Саме тому особливістю Селекційногенетичного інституту, яка завжди виділяла його серед інших закладів аграрної науки, було поєднання теоретичних і селекційних робіт, що протягом кількох десятиріч дозволяло постійно генерувати нові, перспективні напрями досліджень, створювало основу ефективної конкурентоспроможної селекції.

Загалом, 30-ті роки стали періодом формування в інституті колективу кваліфікованих наукових співробітників, досвідчених спеціалістів. Сюди прийшло багато молодих, здібних вчених, які потім принесли установі світове визнання.

Найбільш видатними подіями в довоєнний час були успіхи у селекції пшениці озимої та ярої, ячменю ярого, а також дині, помідорів, соргосуданкових гібридів і деяких інших культур. Так, сорти пшениці озимої Одеська 3 (передана на держсортовипробування у 1937 р.) та Одеська 12 (1939 р.) були виведені Ф. Г. Кириченком, Д. О. Долгушиним, П. Я. Коробко та Л. П. Максимчуком на основі гібридних комбінацій, отриманих ще А. О. Сапєгіним. Ці два сорти в перші повоєнні роки займали щорічно понад 
6 млн га посівних площ. Серед усіх пшениць озимих Одеська 3 за площами посіву посідала на той час перше місце у світі.

у селекції пшениці ярої Д. О. Долгушин створив сорт Одеська 13. У ті ж роки були виведені і сорти ячменю ярого Одеський 9 (автори П. Х. Гаркавий і Л. П. Максимчук) у державному сортовипробуванні 3 1936 р. У 1939 р. П. Х. Гаркавим на держсортовипробування передано сорт Одеський 14.

Результативно велась селекція помідорів та дині О. М. Фаворовим, який створив сорт помідорів Одеський 71 та дині Кримка одеська.

О. М. Фаворов та С. Й. Венгреновський у 1940 р. передали виробництву сорго-суданковий гібрид та суданську траву Одеська 25.

Війна жорстоко обійшлася з інститутом. Після звільнення Одеси навесні 1944 року і повернення співробітників, які перебували в евакуації, а пізніше і тих, хто пройшов довгі бойові шляхи, почалася важка праця з відродження установи - відбудови зруйнованих та ремонту пошкоджених наукових, виробничих, житлових будинків. У ці ж повоєнні роки Ф. Г. Кириченком на матеріалі, повернутому 3 евакуації, було виведено сорт пшениці м'якої озимої Одеська 16. Важливим етапом у науковій роботі стало створення Ф. Г. Кириченком разом із співробітниками вперше в історії землеробства культури пшениці твердої озимої. Тривали роботи також з селекції пшениці твердої та м'якої ярої.

П. Х. Гаркавий завершив виведення видатних сортів ячменю ярого Южний та Степовий, а також сорту-дворучки Одеський 17, який був першим, що витримував зимівлю на півдні України.

О. С. Мусійком разом з П. Ф. Ключко було започатковано в інституті селекцію кукурудзи та створено низку сортів і гібридів - Одеську 10 (що побила усі строки використання у виробництві), Одеський 23, Одеський 27, Одеський 50 МВ.

В інституті тоді вивели також сорт люцерни Зайкевича одеська, здійснювалась селекція бавовника, овочевих культур, однорічних трав.

Успіхи науковців відобразилися у високих державних нагородах інституту - у 1940 р. він був нагороджений орденом Трудового Червоного Прапора, а у 1962-му - орденом Леніна.

Наприкінці 50-х і на початку 60-х років в установі був розширений прийом до аспірантури.

У середині 60-років інститут пережив докорінні зміни, пов'язані з поверненням вітчизняної біологічної науки на матеріалістичний шлях та позбавленням від так званого «мічурінського» напряму, очолюваного Т. Д. Лисенком. Ситуація для інституту була дуже складною тут працювала велика кількість ортодоксальних прибічників «народного академіка», навіть сам інститут носив з 1948 р. його ім'я. На жаль, не всі генетики і селекціонери країни класичної орієнтації виявили мудрість дійсних учених і не робили спроб реваншу. Були й такі, що вважали за потрібне покарати установу, у якій працювали прибічники Лисенка - закрити, або перетворити на дослідну станцію.

У цей критичний час керівництво інституту (директор О. С. Мусійко, заступник директора 3 наукової роботи О. О. Созінов) спромоглося взяти на себе ініціативу і виправити становище. Відбулись кадрові перестановки, в результаті яких на перший план виступила здібна наукова молодь.

у 70-роки в інституті було збудовано найбільшу у світі станцію штучного клімату - фітотрон, на який покладалося завдання якісного удосконалення та прискорення селекційного процесу.

Без перебільшення можна стверджувати, що загальнодержавне значення інституту важко було переоцінити. Наприклад, виведені вченими ВСГІ сорти і гібриди зернових, зернобобових, круп'яних, олійних, кормових культур вирощувались у країні на 10-12 млн га. Крім того, вплив на аграрне виробництво забезпечувався щорічною реалізацією до 1,7 тис. т насіння різних культур. Співробітники установи по праву пишаються тією позитивною роллю, яку інститут відігравав протягом багатьох десятиліть у розвитку сільськогосподарського виробництва у країні.

Після здобуття Україною незалежності Селекційно-генетичний інститут увійшов до системи Української академії аграрних наук. Сьогодні тут створюються сорти пшениці м'якої і твердої озимої, ячменю озимого і ярого, кукурудзи, соняшнику, сої, нуту, гороху, сорго, соризу, люцерни. Справа у тому, що сорт і насіння як у минулому, так і в сучасних умовах залишаються самим дешевим і найбільш важливим фактором підняття аграрного виробництва.

Інститут як і раніше відіграє важливу роль у розвитку сільського господарства країни і регіону. Свого часу кожний третій гектар пшениці озимої в Україні займав сорт Одеська 51, виведений Д. О. Долгушиним. I сьогодні сорти інституту висіваються у нашій країні щорічно на 3-4 млн га. Селекційний конвейєр, який працює в СГІ, дає можливість постійно удосконалювати набір сортів, підвищувати стабільність і якість отримуваної продукції.

Сьогодні метою робіт з селекції озимої пшениці (розпочатих 
в 1912 р.), які очолюють академіки НААН М. А. Литвиненко та С. П. Лифенко, $\epsilon$, перш за все, створення сортів інтенсивного типу з підвищеними адаптивними властивостями універсального використання на різних агрофонах. За ознаками жаро- i посухостійкості одеські пшениці, без перебільшення, є кращими у світі. Але найбільш вираженими ознаками, які відрізняють їх від інших сортів, $\epsilon$ винятково високі показники якості зерна сильних і екстрасильних пшениць. Такі сорти відкривають можливість отримати «сильне» зерно в регіонах, які раніше такого не вирощували.

Останніми роками в інституті створені сорти пшениці озимої 3 груповою та комплексною стійкістю до поширених захворювань. Продовжується робота 3 удосконалення напівкарликових сортів, які практично не вилягають і витримують найбільш високі агрофони та інтенсивні дощі.

Уваги заслуговують сортипшениці твердої озимої - культури, вперше у світовій селекції створеної в Селекційно-генетичному інституті в 1960 р. Ф. Г. Кириченком. Показники якості макаронів у них знаходяться на рівні кращих світових стандартів.

Селекцію ячменю в інституті було розпочато в 1916 р. У даний час висока результативність робіт зі створення сортів ячменю ярого та озимого (керівник академік НАAН А. А. Лінчевський) пов'язана $з$ розробкою та впровадженням концепції на пристосованість до мінливих умов вирощування. Науковцями створено новий тип шестирядних сортів високоінтенсивного типу, встановлено генотип сортів-дворучок і розроблено шляхи їхнього цілеспрямованого селектування.

У селекції ячменю озимого було розроблено програму на- дання сортам стійкості до сажкових захворювань, яка втілилась у виведення сортів з груповою стійкістю до збудників чорної (Ustilago nigza), твердої (Ustilago hozdei) та летючої (Ustilago nuda) видів сажки.

Дослідження з селекції кукурудзи (керівник робіт - членкореспондент НААН В. М. Соколов, директор інституту) спрямовані на виведення гібридів найбільш пріоритетних напрямів використання - скоростиглих для зони Лісостепу i Полісся (ФАО 150-299), середньостиглих і середньоранніх інтенсивного типу для степової зони (ФАО 300-450), зернового та силосного призначення. Серед важливих робіт останніх років - розробка та впровадження у селекційний процес технології молекулярних маркерів. У виробництві набули поширення гібриди кукурудзи з високою адаптивністю, зокрема жаро-, посухостійкістю, високою та стабільною зерновою продуктивністю. Потенціал їх урожайності сягає 12,0-16,9 т/га зерна і 8085 т/га силосної маси.

Селекціонерам інституту належить пріоритет у створенні перших вітчизняних високоолійних, стійких до основних хвороб, перш за все до вовчка, гібридів соняшнику (В. В. Бурлов). Виведені за останні роки гібриди (Б. Ф. Вареник, В. І. Крутько) вирізняються генетично зумовленою стійкістю до вовчка, несправжньої борошнистої роси, толерантністю до загущення та мають зручне промислове насінництво.

Роботи із зернобобовими культурами, зокрема з горохом, спрямовані на виведення сортів, адаптованих до вирощування в умовах півдня України, стійких до найбільш поширених захворювань, з поліпшеними якісними властивостями отримуваної продукції, технологічних у виробництві. Накопичені знання сприяли створенню сорту гороху Світ. Суттєвим науковим успіхом $\epsilon$ виведення протягом останніх 35 років близько 30 сортів сої, придатних для кормового та харчового використання (В. I. Січкар), а також крупнонасінних сортів нуту з масою 1000 насінин більше 400 г (О. В. Бушулян).

Всі сорти люцерни, створені в інституті, мають високу насіннєву продуктивність, яка при дотриманні вимог технології та задовільному забезпеченні запилювачами може сягати на богарі 0,4-0,5 т/га, а при зрошенні до 1,0 т/га.

Загалом, у Державному реєстрі сортів рослин України станом на 2012 р. налічується 179 сортів та гібридів, виведених у СГІ.

Селекційна робота в інституті, як кінцевий результат діяльності установи, базується на здійснюваних тут теоретичних дослідженнях 3 підвищення продуктивності, стійкості до несприятливих умов середовища, збудників хвороб, поліпшення якісних ознак рослин, вибору оптимальної тривалості вегетаційного періоду і т. ін. Серед теоретичних підрозділів слід відзначити, перш за все, роботу відділів генетики, генетичних основ селекції, геноміки і біотехнології, фітопатології і ентомології.

Важливою подією став приїзд до інституту з Мінського університету А. Ф. Стельмаха, нині широко відомого у світі і Україні вченого, який започаткував тут дійсно генетичні дослідження та сприяв підвищенню рівня підготовки $з$ генетики науковців і молоді в аспірантурі. Нині відділом завідує його учень - В. І. Файт.

у 70-ті роки у біологічній науці почав розвиватися новий напрям - молекулярна біологія. У країні не було фахівців з цієї га- 
лузі і тому молодий науковець Ю. М. Сиволап був направлений на стажування у США до відомого вченого Дж. Боннера. Повернувшись, Сиволап очолив лабораторію молекулярної біології, яка у майбутньому у статусі Південного біотехнологічного центру в рослинництві стала осередком молекулярногенетичних і біотехнологічних досліджень в аграрній науці.

Створений О. О. Созіновим відділ генетичних основ селекції, який у подальшому очолювали його вихованці, Ф. О. Попереля, а згодом О. І. Рибалка, є прикладом участі генетиків, спеціалістів з технологічних якостей зерна у забезпеченні селекційного процесу. Науковцями відділу розробляються методи оцінки селекційних зразків, створюється вихідний матеріал на основі інтрогресивної гібридизації, контролюється генетична чистота насіння за допомогою електрофоретичного аналізу білків зерна та ферментів.

Багаторічний керівник відділу фітопатології та ентомології, відомий фахівець із захисту рослин Е. Е. Гешеле почав працювати ще у А. О. Сапєгіна і належав до учених, які створювали фітопатологічну науку в країні. Від Е. Е. Гешеле відділ прийняв його учень Л. Т. Бабаянц, який розгорнув роботу з оцінки селекційних ліній і зразків на стійкість до хвороб та шкідників, 3 вивчення генетичної природи стійкості рослин до патогенів, пошуку джерел і донорів стій- кості до основних захворювань. у даний час естафету від цих вчених прийнято новим завідувачем відділу - О. В. Бабаянц.

В інституті діє Технічний комітет зі стандартизації - ТК 110 «Насіння сільськогосподарських культур» для вдосконалення чинних та розробки нових насіннєвих стандартів.

Загальна реалізація інститутом та його дослідними господарствами насіння ярого, озимого ячменю та озимої пшениці за 2007-2011 рр. склала 53738,3 тонн, а разом 3 кукурудзою, олійними і зернобобовими 82992,2 тонн.

Досягнення інституту стали результатом плідної роботи багатьох видатних учених, які працювали тут, зокрема академіків та членів-кореспондентів АН СРСР, УРСР, ВАСГНІЛ А. О. Сапєгіна, Ф. Г. Кириченка, П. Х. Гаркавого, Д. О. Долгушина, О. С. Мусійко, О. О. Созінова. Їхні традиції сьогодні плідно продовжують академіки та члени-кореспонденти НААН С. П. Лифенко, М. А. Литвиненко, А. А. Лінчевський, А. Ф. Стельмах, Ю. М. Сиволап, В. М. Соколов (директор інституту), С. В. Чеботар, доктори наук А. О. Бєлоусов, Г. К. Дремлюк, B. I. Січкар, О. I. Рибалка, В.І.Файт,М.О.Кіндрук,О.В.Бабаянц, С. О. Ігнатова, Н. Е. Волкова, кандидати наук Л. Т. Бабаянц, О. В. Бушулян, Б. Ф. Вареник, В. В. Вишневський, В. І. Крутько, А. I. Паламарчук, ряд інших. Загалом, в інституті працюють 364 особи, зокрема 112 наукових співробітників. Серед них 15 докторів наук та 61 кандидат наук.

Протягом двох десятиріч інститут виконував функції Координаційного центру країн-членів Ради Економічної Взаємодопомоги з розробки теоретичних основ селекції, насінництва та нових методів створення сортів сільськогосподарських культур. Як Південно-Західний селекцентр ВАСГНІЛ СГІ координував селекційно-насінницьку роботу із зерновими, зернобобовими, кормовими культурами в наукових установах південних областей України та в Молдові, а в межах СРСР з теоретичних питань та селекції ячменю. I сьогодні інститут виконує функції координаційного центру Національної академії аграрних наук України.

Статус Національного центру присвоєний установі постановою Кабінету Міністрів України в 1999 році.

Інститут підтримує двосторонні угоди із зарубіжними науковими установами, фірмами з Французької Республіки, Угорщини, Російської Федерації, Республіки Молдова, Турецької Республіки, Румунії, США, Республіки Індія, Королівства Таїланд, на основі яких здійснюється створення сортів, обмін науковими розробками, генетичним і вихідним селекційним матеріалом.

Селекційно-генетичний інститут зберігає свої наукові позиції, забезпечує вирішення завдань державних наукових програм та впевнено дивиться у майбутнє. 